\title{
PENGARUH PROGRAM PARENTING TERHADAP PERKEMBANGAN KEMANDIRIAN ANAK USIA DINI (STUDI PADA PAUD PARAMATA BUNDA KOTA PALOPO)
}

\author{
Syamsu S. \\ FTIK Institut Agama Islam Negeri (IAIN) Palopo \\ E-mail: syam1954783@gmail.com
}

\begin{abstract}
This study aims to determine the effect of parenting program on the development of early child self-reliance at PAUD Paramata Bunda Palopo. The type of this research is descriptive quantitative expost facto model, which result is described in the form of percentage or number. The study population amounted to 172 people (160 parent learners, 12 teachers) parent sample of students taken $20 \%=32$ people (variable X). While the population as well as the sample of teachers as many as 12 people (variable Y). Data collection techniques are questionnaires, interviews, and documentation. Further analysis of quantitative descriptive data in the form of percentage technique and mean score. The results showed that the implementation of parenting programs positively influences the development of child self-reliance in PAUD Paramata Mother of Palopo City. The implication of this research is that every parent has moral obligation to participate in the implementation of educational programs so that synchronization between parent and school side toward early child development stage.
\end{abstract}

Key Words: Parenting Program, Development of Independence

\begin{abstract}
Abstrak
Penelitian ini bertujuan untuk mengetahui pengaruh pelaksanaan program parenting terhadap perkembangan kemandirian anak usia dini pada lembaga PAUD Paramata Bunda kota Palopo. Jenis penelitian ini adalah deskriptif kuantitatif model expost facto, yang hasilnya dideskripsikan dalam bentuk persentase atau angka-angka. Populasi penelitian berjumlah 172 orang (160 orang tua peserta didik, 12 orang guru) sampel orang tua peserta didik diambil $20 \%=32$ orang (variabel X). Sedangkan populasi sekaligus sampel pihak guru sebanyak 12 orang (variabel Y). Teknik pengumpulan data yaitu angket, wawancara, dan dokumentasi. Selanjutnya analisis data deskriptif kuantitatif dalam bentuk teknik persentase dan mean score. Hasil penelitian menunjukkan bahwa pelaksanaan program parenting berpengaruh positif terhadap perkembangan kemandirian anak pada PAUD Paramata Bunda Kota Palopo. Implikasi penelitian ini adalah setiap orang tua memiliki kewajiban moral untuk berpartisipasi pada pelaksanaan program-program pendidikan agar terjadi sinkronisasi antara orang tua dengan pihak sekolah terhadap tahapan perkembangan anak usia dini.
\end{abstract}

Kata Kunci: Program Parenting, Perkembangan Kemandirian

\section{PENDAHULUAN}

Anak usia dini tengah tumbuh dan berkembang, berjalan mengikuti hukum perkembangan, artinya secara umum manusia berkembang mulai dari janin, bayi, kanak-kanak, remaja, dewasa dan tua; yang kecepatan perkembangannya berbeda-beda, mulai dari cepat, stabil dan melambat, dan 
berhenti. Semakin tinggi usianya semakin banyak pengalaman yang diperoleh sehigga semakin banyak kemampuan yang didapat anak.

Kemandirian merupakan salah satu aspek kepribadian manusia yang tidak berdiri sendiri karena terkait dengan aspek kepribadian yang lain dan harus dilatihkan pada anak sedini mungkin agar tidak menghambat tugastugas perkembangan anak selanjutnya. Tugas perkembangan anak pada usia dini adalah untuk mencapai kemandirian. Kemandirian akan tercapai secara penuh pada akhir masa remaja, namun kemandirian tidak akan pernah tercapai atau hanya akan tercapai sebagian jika perkembangan pada masa awal kanak-kanak tidak memberi dasar yang baik.

Anak-anak yang tidak dilatih mandiri sejak usia dini, akan menjadi individu yang tergantung sampai remaja bahkan sampai dewasa nanti. Contoh yang paling nyata adalah anak usia SD yang makan masih harus disuapi, dimandikan atau masih banyak dibantu dalam kegiatan yang seharusnya sudah dapat dilakukan sendiri. Kemampuan diperoleh seseorang secara bertahap, yakni sedikit demi sedikit. Semakin besar seseorang semakin bertambah pula kemampuan pendengaran, penglihatan, dan akalnya hingga sampailah ia pada usia matang dan dewasa. Dengan bekal pendengaran, penglihatan, dan hati nurani pada perkembangan anak selanjutnya akan memperoleh pengaruh sekaligus berbagai didikan dari lingkungan sekitarnya.

Pengembangan potensi pada anak usia dini umur 2-6 tahun menjadi penting, karena mereka itu masih sangat labil, mudah terbawa arus, mudah terpengaruh. Karena itu PAUD Paramata Bunda Kota Palopo melakukan bimbingan, proses latihan serta pembiasaan yang terus menerus. Pembinaan potensi kemandirian perlu ditanamkan sejak anak usia prasekolah, lingkungan keluarga adalah tempat yang pertama dan utama bagi anak untuk memperoleh pembinaan mental dan pembentukan kepribadian, yang kemudian disempurnakan oleh sekolah.

Pembinaan nilai-nilai untuk pengembangan potensi berbasis agama telah dilakukan dengan baik oleh pada lembaga PAUD Paramata Bunda Kota Palopo. Mereka memberikan pembinaan nilai-nilai sejak tahun pertama. Pemberian pembinaan nilai-nilai bagi peserta didik di Paramata Bunda Kota Palopo diharapkan dapat menghasilkan generasi yang berakhlak mulia, mandiri, dan berprestasi optimal.

Bertolak dari latar belakang di atas maka bahasan hasil penelitian ini meliputi: 1) Pelaksanaan program parenting pada PAUD Paramata Bunda kota Palopo; 2) Perkembangan kemandirian anak pada PAUD Paramata Bunda kota Palopo; dan 3) Pengaruh pelaksanaan program parenting terhadap perkembangan kemandirian anak pada PAUD Paramata Bunda kota Palopo. 


\section{METODE}

Jenis penelitian ini adalah deskriptif kuantitatif model expost facto. Populasi penelitian ini adalah orang tua peserta didik berjumlah 160 orang, dan guru PAUD Paramata Bunda Kota Palopo berjumlah 12 orang. Jadi jumlah populasi penelitian seluruhnya 172 orang. Adapun sampel penelitian ini diambil sebesar 20 persen $^{1}$ dari jumlah populasi orang tua peserta didik, yaitu $20 \%$ x $160=32$ orang (random sampling) sekaligus sebagai sumber data untuk memeroleh data variabel X (pengaruh program parenting). Sampel untuk guru diambil seluruhnya (total sampling), yaitu 12 orang sekaligus sebagai sumber untuk memperoleh data variabel Y (perkembangan kemandirian peserta).

Analisis data yang digunakan adalah statistik deskriptif yaitu menggambarkan kegiatan berupa pengumpulan data, penyusunan data, pengolahan data, dan penyajian data dalam bentuk tabel agar mendapatkan gambaran yang jelas tentang pengaruh pelaksanaan program parenting terhadap perkembangan kemandirian peserta didik pada PAUD Paramata Bunda kota Palopo meliputi: nilai tertinggi, nilai terendah, nilai rata-rata, standar deviasi, dan tabel distribusi frekuensi. ${ }^{2}$ Teknik analisis data ini berpedoman pada langkah-langkah analisis penelitian deskripftif kuantitatif, yaitu persentase dan mean score.

Sedangkan kriteria yang digunakan untuk menentukan kategori pelaksanaan program parenting, dan perkembangan kemandirian peserta didik pada PAUD Paramata Bunda adalah menggunakan skala likert. Jawaban setiap item instrumen angket yang digunakan terdiri atas 4 alternatif mempunyai gradasi dari sangat positif sampai sangat negatif, berupa kata-kata yaitu: Sangat Sering (SS) = 4, Sering $(S)=3$, Kadang-kadang $(K K)=2$, dan tidak pernah $(\mathrm{TP})=1 .{ }^{3}$ Dengan demikian, maka hasil analisis data tersebut dipresentasikan dalam tabel distribusi.

\section{TERMINOLOGI DAN KARAKTERISTIK ANAK USIA DINI}

Anak usia dini kini sudah lazim dikenal dan telah tersosialisasi pada kalangan pendidik. Istilah anak usia dini merupakan modernisasi istilah anak prasekolah. Terminologi anak usia dini disebutkan oleh Sudarwan Danim yaitu anak yang berumur 2 sampai 6 tahun atau tahun-tahun prasekolah atau masa menjalani pendidikan anak usia dini (PAUD), baik formal maupun

${ }^{1}$ Suharsimi Arikunto, Prosedur Penelitian Suatu Pendekatan Praktik, (Cet. XIII; Jakarta: Rineka Cipta, 2006), h.134

${ }^{2}$ Subana dan Sudrajat, Dasar-dasar Penelitian Ilmiah (Cet. II; Bandung: Pustaka Setia, 2005), h. 95 .

${ }^{3}$ Sugiyono, Metode Penelitian Kuantitatif Kualitatif dan R\&B, op. cit., h.94. 
nonformal. ${ }^{4}$ Secara legal formal, terminologi anak usia dini dirumuskan dalam Undang-Undang Republik Indonesia Nomor 20 Tahun 2003 tentang Sistem Pendidikan Nasional pada Pasal 1 ayat 14 bahwa pendidikan anak usia dini adalah suatu upaya pembinaan yang ditujukan kepada anak sejak lahir sampai dengan usia enam tahun yang dilakukan melalui pemberian rangsangan pendidikan untuk membantu pertumbuhan dan perkembangan jasmani dan rohani agar anak memiliki kesiapan dalam memasuki pendidikan lebih lanjut. ${ }^{5}$ Klasifikasi umur masa anak usia dini ada yang melihatnya dimulai dari sejak lahir yakni umur 0-6 tahun, ada pula yang melihatnya dimulai dari umur 2-6 tahun. Zakiyah Daradjat mengklasifikasikan masa anak itu menjadi dua masa yakni masa umur 0-6 tahun dan umur 6-12 tahun yang masing-masing tahap mempunyai karakeristik berbeda pada kepribadian anak. ${ }^{6}$

Selanjutnya, pada pasal 28 diatur tentang penyelenggaraan pendidikan anak usia dini, yaitu:

1. Pendidikan anak usia dini dapat diselenggarakan melalui jalur pendidikan formal, nonformal, dan/atau informal.

2. Pendidikan anak usia dini pada jalur pendidikan formal berbentuk Taman Kanak-kanak (TK), Raudatul Athfal (RA), atau bentuk lain yang sederajat.

3. Pendidikan anak usia dini pada jalur pendidikan nonformal berbentuk Kelompok Bermain (KB), Taman Penitipan Anak (TPA), atau bentuk lain yang sederajat. ${ }^{7}$

Dalam penyelenggaraan pendidikan anak usia dini, dibutuhkan guru yang memenuhi kualifikasi akademik dan kompetensi guru PAUD. Hal ini didasarkan pada Peraturan Menteri Pendidikan Nasional Republik Indonesia Nomor 16 tahun 2007 tentang Standar Kualifikasi Akademik dan Kompetensi Guru. Pada lampiran peraturan tersebut, disebutkan kualifikasi akademik guru PAUD/TK/RA harus memiliki kualifikasi akademik pendidikan minimum diploma empat (D-IV) atau sarjana (S1) dalam bidang pendidikan anak usia dini.

Berdasarkan pengertian tersebut di atas dapat dipahami bahwa pendidikan anak usia dini (PAUD) merupakan upaya pembinaan dan pengembangan yang ditujukan kepada anak sejak lahir sampai dengan usia enam tahun. Kegiatan itu dilakukan melalui pemberian rangsangan pendidikan untuk membantu pertumbuhan dan perkembangan jasmani dan rohani agar anak memiliki kesiapan dalam memasuki pendidikan lebih lanjut.

45.

${ }^{4}$ Sudarwan Danim, Perkembangan Peserta Didik, (Cet. I; Bandung: Alfabeta, 2010), h.

5 Republik Indonesia, Undang-Undang Nomor 20 Tahun 2003 tentang Sistem Pendidikan Nasional, (Cet. IV; Jakarta: Sinar Grafika, 2011), h. 4.

6Zakiyah Daradjat, Ilmu Jiwa Agama, (Cet. V; Jakarta: Bulan Bintang, 2005), h. 126.

${ }^{7}$ Ibid, h. 19. 
Selanjutnya, dikemukakan tentang karakteristik anak usia dini. Secara umum, masa ini memiliki karateristik atau sifat-sifat sebagaimana dikemukakan Syamsu Yusuf dalam M. Ali yaitu:

1. Unik. Artinya sifat anak itu berbeda satu sama lainnya. Anak memiliki bawaan, minat, kapabilitas, dan latar belakang kehidupan masing-masing.

2. Egosentris. Anak lebih cenderung melihat dan memahami sesuatu dari sudut pandang dan kepentingannya sendiri.

3. Aktif dan energik. Anak lazimnya senang melakukan berbagai aktivitas. Selama terjaga dari tidur, anak seolah-olah tidak pernah lelah, tidak pernah bosan, dan tidak pernah berhenti dari aktivitas.

4. Rasa ingin tahu yang kuat dan antusias terhadap banyak hal.

5. Eksploratif dan berjiwa petualang.

6. Spontan. Perilaku yang ditampilkan anak umumnya relatif asli dan tidak ditutup-tutupi sehingga merefleksikan apa yang ada dalam perasaan dan pikirannya.

7. Senang dan kaya dengan fantasi. Anak senang dengan hal-hal yang imajinatif.

8. Masih mudah frustrasi. Umumnya anak masih mudah frustrasi, atau kecewa bila menghadapi sesuatu yang tidak memuaskan. ${ }^{8}$

\section{TAHAPAN PERKEMBANGAN ANAK USIA DINI}

Perkembangan anak usia dini dapat dilihat pada ciri tahapan meliputi: perkembangan jasmani, perkembangan kognitif, perkembangan bahasa, dan perkembangan emosi dan sosial. Keempat perkembangan ini dijelaskan sebagai berikut.

1. Perkembangan jasmani. Perkembangan jasmani pada tahapan usia dini (3-6 tahun) memiliki ciri yang jelas setiap selang waktu dapat berubah pada diri seorang anak. Perubahan tersebut dapat dilihat pada proporsi tubuh, berat dan tinggi badan yang mereka miliki. Pertumbuhan dan perkembangan jasmani tersebut banyak dipengaruhi oleh gizi, kesehatan, dan lingkungan fisik lainnya. ${ }^{9}$

2. Perkembangan kognitif. Perkembangan kognitif sering diartikan sebagai kecerdasan atau berpikir. Perkembangan ini terjadi antara umur 2 dan 6 tahun sebagai tahap praoperasional. Pada tahap ini, anak-anak meningkatkan penggunaan bahasa dan simbol lainnya, mereka meniru

${ }^{8}$ Syamsu Yusuf L.N., dan Nani M. Sugandhi, Perkembangan Peserta Didik, (Cet. III; Jakarta: RajaGrafindo Persada, 2012), h. 48-50.

${ }^{9}$ Soemiarti Patmonodewo, Pendidikan Anak Prasekolah, (Cet. I; Jakarta: Rineka Cipta, 2000), h. 25. 
perilaku dan permainan orang dewasa. Anak-anak mengembangkan daya tarik dengan bahasa atau kata-kata baik dan buruk. ${ }^{10}$

3. Perkembangan bahasa. Sementara anak tumbuh dan berkembang, produk bahasa mereka meningkat dalam kuantitas, keluasan dan kerumitannya. Mempelajari perkembangan bahasa biasanya ditujukan pada rangkaian dan percepatan perkembangan dan faktor-faktor yang mempengaruhi perolehan bahasa sejak usia bayi dan dalam kehidupan selanjutnya.

4. Perkembangan emosi dan sosial. Setiap anak mempunyai rasa senang, marah, jengkel dalam menghadapi lingkungan sehari-hari. Hal ini mempengaruhi perkembangan wawasan sosial anak. ${ }^{11}$ Perkembangan ini biasanya dimaksudkan sebagai perkembangan tingkah laku anak dalam menyesuaikan diri dengan aturan-aturan yang berlaku di dalam masyarakat di mana anak berada.

Di antara berbagai ragam kegiatan di kelas, bermain merupakan kegiatan yang sangat mendukung perkembangan anak terutama dalam perkembangan kemandirinnya. Selain itu, aspek mampu memilih benda untuk bermain, mampu mengerjakan tugas sendiri, bermain sesuai dengan jenis permainan yang dipilihnya, dan mengurus dirinya sendiri dengan bantuan, misalnya: berpakaian, gosok gigi, pakai sepatu.

\section{PROGRAM PARENTING}

Istilah parenting yang berarti keterlibatan orang tua, kini sudah lazim dan familiar dalam dunia pendidikan terutama pada lembaga pendidikan anak usia dini (PAUD). Soemiarti Patmonodewo mendefinisi parenting yaitu suatu proses di mana orang tua menggunakan segala kemampuan mereka, guna keuntungan mereka sendiri, anak-anaknya, dan program yang dijalankan anak itu sendiri. ${ }^{12}$

Keterlibatan orang tua adalah suatu keniscayaan bahwa orang tua adalah guru pertama bagi anak-anaknya. Apabila anak telah masuk sekolah, orang tua adalah mitra kerja yang utama bagi guru anaknya. Bahkan sebagai orang tua, mereka mempunyai berbagai pilihan yaitu: orang tua sebagai pelajar, orang tua sebagai relawan, orang tua sebagai pembuat keputusan, orang tua sebagai tim kerjasama guru-orang tua. Dalam peran-peran tersebut memungkinkan orang tua membantu meningkatkan perkembangan dan pertumbuhan anak-anak mereka.

Heinz (1979) dalam Soemiarti Patmonodewo menjelaskan bahwa ada 3 hal yang penting apabila orang tua dan pihak sekolah dapat menjalin kerjasama yaitu: konsep diri orang tua dan anak akan meningkat, motivasi

\footnotetext{
${ }^{10}$ Sudarwan Danim, op. cit., h. 49.

11Ibid., h. 30.

12Ibid., h. 124.
} 
belajar anak meningkat, dan prestasi yang dicapai anak akan meningkat pula. ${ }^{13}$

Pendapat Heinz tersebut menjadi landasan yang objektif pentingnya program parenting, atau keterlibatan orang tua dalam pembinaan pendidikan pada lembaga pendidikan anak usia dini (PAUD). Partisipasi orang tua di sekolah secara umum dapat meningkatkan prestasi anak di sekolah. Apabila memiliki program sekolah yang baik dan orang tua mau membantu, umumnya prestasi dan keterampilan anak akan meningkat.

Soemiarti Patmonodewo dalam Sunarto menyakini bahwa keterlibatan orang tua di sekolah akan meringankan guru dalam membina kepercayaan diri anak, mengurangi masalah disiplin anak, dan meningkatkan motivasi anak. Para guru menganggap orang tua sebagai pasangan atau rekan kerja yang penting dalam pendidikan prasekolah, akan makin menghargai dan makin terbuka terhadap kesediaan kerjasama orang tua. ${ }^{14}$

Karena itu, program parenting (keterlibatan orang tua) dalam kegiatan di sekolah akan memberi keuntungan, yaitu orang tua akan mendapat kesempatan belajar cara meningkatkan pertumbuhan dan perkembangan anak. Para orang tua akan merasa lebih mampu dan dibutuhkan dalam kegiatan pembelajaran anak mereka di sekolah. Selain itu para orang tua akan mendapat kesempatan mengembangkan hubungan dengan orang tua lain di sekolah.

\section{PELAKSANAAN PROGRAM PARENTING PADA PAUD PARAMATA BUNDA}

Paparan sebelumnya, dikemukakan asumsi mengenai program parenting adalah suatu program yang dilaksanakan oleh PAUD Paramata Bunda di mana melibatkan peran serta orang tua untuk menggunakan segala kemampuan mereka, guna keuntungan anak-anaknya dan mereka sendiri.

Hasil penelitian menunjukkan bahwa program parenting pada PAUD Paramata Bunda Kota Palopo meliputi:

1. Kegiatan opening school yang melibatkan seluruh orang tua pada;

2. Silaturrahim dengan orang tua setiap bulan (membahas perkembangan anak);

3. Memperingati hari besar keagamaan dan hari besar nasional (17 Agustus, maulid nabi saw., isra'mi'raj, kurban, praktik haji);

4. Tadabbur alam (memperkenalkan pada anak macam-macam tumbuhan);

5. Life skill (membuat asesoris, bros dan memasang payet;

13 Ibid.

${ }^{14}$ Sunarto, Perkembangan Peserta Didik, (Cet. II; Jakarta: Rineka Cipta, 2002), h. 5. 


\section{Workshop parenting; dan}

7. Senam massal dan jalan santai setiap akhir semester. ${ }^{15}$

Ketujuh macam program parenting tersebut, peneliti jadikan sebagai bahan untuk memperoleh deskripsi pelaksanaan program parenting dalam penyelenggaraan pendidikan pada PAUD Paramata Bunda Kota Palopo. Untuk kepentingan pengumpulan data, peneliti mengedarkan angket kepada orang tua peserta didik sebanyak 32 orang. Hasil analisis data dapat dilihat pada akumulasi data pelaksanaan program parenting pada PAUD Paramata Bunda Kota Palopo sebagaimana dipresentasikan berikut.

Tabel 1

Akumulasi Data Pelaksanaan Program Parenting pada PAUD Paramata Bunda Kota Palopo (Variabel X)

\begin{tabular}{ccccccc}
\hline \multirow{2}{*}{ No. } & No. Program & \multicolumn{4}{c}{ Kategori Jawaban Responden } & \multirow{2}{*}{ Skor } \\
\cline { 2 - 5 } & Parenting & SS & S & KK & TP & \\
\hline 1 & Program 1 & 28 & 2 & 2 & 0 & 122 \\
2 & Program 2 & 25 & 4 & 3 & 0 & 118 \\
3 & Program 3 & 26 & 4 & 2 & 0 & 120 \\
4 & Program 4 & 24 & 6 & 2 & 0 & 118 \\
5 & Program 5 & 30 & 2 & - & 0 & 126 \\
6 & Program 6 & 26 & 3 & 3 & 0 & 119 \\
7 & Program 7 & 24 & 6 & 2 & 0 & 114 \\
\hline & & Jumlah
\end{tabular}

Sumber data: hasil analisis angket no. 1-7

Data pada tabel di atas menunjukkan terdapat skor sebesar 827 sedangkan skor ideal (kriterium) untuk seluruh item sebesar 4 × 32 × $7=896$ (jika sejumlah 32 responden memilih kategori sangat sering pada 7 nomor angket), sehingga skor rerata $827: 7=118,142: 32=3,69$ lebih dekat pada skor 4 adalah kategori sangat sering dengan persentase sebesar $827: 896 \mathrm{x}$ $100 \%=92,30 \%$ berada pada interval 85 sampai dengan 100 adalah kategori sangat tinggi.

Berdasarkan hasil analisis tersebut, dapat disimpulkan bahwa pelaksanaan program parenting pada PAUD Paramata Bunda Kota Palopo adalah kategori sangat tinggi, yaitu berada pada persentase 92,30\%. Kesimpulan ini berkorelasi dengan hasil wawancara dari salah seorang guru yang menyatakan bahwa partisipasi orang tua peserta didik untuk ikut serta dalam setiap kegiatan atau program pendidikan sangat tinggi. Itulah yang menjadi salah satu faktor PAUD Paramata Bunda mendapat apresiasi dari

15Dokumentasi pada kantor PAUD Paramata Bunda Kota Palopo, 2017. 
pemerintah Kota Palopo di mana PAUD ini mendapat status akreditasi A (Amat Baik). ${ }^{16}$

Berdasarkan uraian di atas, menunjukkan bahwa pelaksanaan program parenting pada PAUD Paramata Bunda berada pada persentase 92,30\% atau kategori sangat baik. Presentase ini diperoleh karena perhatian orang tua peserta didik pada program tersebut sangat tinggi.

\section{PERKEMBANGAN KEMANDIRIAN ANAK}

Pembahasan sebelumnya pada telah dipaparkan bahwa ruang lingkup standar kompetensi pendidikan anak usia dini dikembangkan berdasarkan aspek perkembangan anak yang meliputi enam aspek: yaitu 1) aspek perkembangan moral dan nilai-nilai agama; 2) aspek perkembangan sosial, emosional, dan kemandirian; 3) aspek perkembangan bahasa; 4) aspek perkembangan kognitif; 5) aspek perkembangan fisik/motorik; 6) aspek perkembangan seni. Terkait dengan penelitian ini, maka aspek perkembangan kemandirian (aspek 2) anak usia 2-6 tahun terdiri atas 24 indikator perkembangan. Setelah dilakukan simplikasi terhadap beberapa indikator yang mempunyai kesamaan fungsi, peneliti mengambil tujuh indikator perkembangan aspek kemandirian, yaitu:

1. Mampu berpisah dengan orangtuanya tanpa menangis;

2. Memilih kegiatan sendiri;

3. Bermain sesuai dengan jenis permainan yang dipilihnya;

4. Mengurus dirinya dengan bantuan (makan, minum, kegiatan toilet, berpakaian, memasang dan membuka tali sepatu);

5. Berani pergi dan pulang sekolah sendiri (bagi yang dekat dengan sekolah);

6. Mampu mandi sendiri, gosok gigi, BAK dan BAB (toilet training); dan

7. Mengerjakan tugas sendiri.

Ketujuh macam indikator aspek perkembangan kemandirian tersebut, peneliti jadikan bahan untuk memperoleh deskripsi tentang perkembangan kemandirian anak usia dini pada PAUD Paramata Bunda Kota Palopo. Untuk kepentingan pengumpulan data, peneliti mengedarkan angket kepada semua guru pada PAUD Paramata Bunda Kota Palopo sejumlah 12 orang. Hasil analisis dapat dilihat pada akumulasi data tentang pelaksanaan program parenting pada PAUD Paramata Bunda Kota Palopo sebagaimana dipresentasikan berikut.

16Indra Kusuma, guru PAUD Paramata Bunda Kota Palopo, wawancara, 26 Agustus 
Tabel 2

Akumulasi Data Perkembangan Kemandirian Peserta Didik pada PAUD Paramata Bunda Kota Palopo

(Variabel Y)

\begin{tabular}{ccccccc}
\hline \multirow{2}{*}{ No. } & No. Indikator & \multicolumn{4}{c}{ Kategori Jawaban Responden } & \multirow{2}{*}{ Skor } \\
\cline { 3 - 6 } & & SS & S & KK & TP & \\
\hline 1 & Indikator 1 & 8 & 2 & 2 & - & 42 \\
2 & Indikator 2 & 6 & 4 & 2 & - & 40 \\
3 & Indikator 3 & 10 & 2 & - & - & 46 \\
4 & Indikator 4 & 4 & 6 & 2 & - & 38 \\
5 & Indikator 5 & - & 1 & 2 & 9 & 16 \\
6 & Indikator 6 & 6 & 4 & 2 & - & 40 \\
7 & Indikator 7 & 7 & 3 & 2 & - & 41 \\
\hline & & Jumlah & & & & 263
\end{tabular}

Sumber data: hasil analisis angket no. 1-7

Data pada tabel di atas, menunjukkan terdapat skor sebesar 263 sedangkan skor ideal (kriterium) untuk seluruh item sebesar 4 x 12 x $7=336$ (jika sejumlah 12 responden memilih kategori sangat sering pada 7 nomor angket), sehingga skor rerata $263: 7=37,58: 12=3,13$ lebih dekat pada skor 3 adalah kategori sering dengan persentase sebesar $263: 336 \times 100 \%=$ $78,27 \%$ berada pada interval 75 sampai dengan 84 adalah kategori tinggi.

Berdasarkan hasil analisis di atas, dapat disimpulkan bahwa perkembangan kemandirian peserta didik pada PAUD Paramata Bunda Kota Palopo kategori baik, yaitu berada persentase 78,27\%. Kesimpulan ini berkorelasi dengan hasil wawancara dari salah seorang guru yang menyatakan bahwa secara umum anak-anak kami di sini pada pintar, berani mandiri, saling mengajak bermain bersama. Jadi kami merasa puas melihat perkembangan sikap kemandirian anak-anak kami. ${ }^{17}$

Berdasarkan uraian di atas, menunjukkan bahwa perkembangan kemandirian peserta didik pada PAUD Paramata Bunda berada pada persentase $78,27 \%$ atau ketegori baik.

\section{PENGARUH PELAKSANAAN PROGRAM PARENTING TERHADAP PERKEMBANGAN KEMANDIRIAN PESERTA DIDIK PADA PAUD PARAMATA BUNDA KOTA PALOPO}

Pendidikan kepribadian yang mengembangkan aspek kemandirian sesungguhnya jauh lebih berat daripada pengajaran pengetahuan. Pembinaan kemandirian dimaksudkan untuk pembinaan sikap dan kepercayaan. Karena itu, guru yang ideal adalah yang dapat menunaikan dua fungsi sekaligus, yaitu sebagai guru dan sebagai dokter jiwa yang dapat membekali anak dengan

\footnotetext{
${ }^{17}$ Sabiarni, guru PAUD Paramata Bunda Kota Palopo, wawancara, 26 Agustus 2017.
} 
pengetahuan agama serta dapat membina kepribadian anak menjadi seorang yang mampu bertanggung jawab dan mandiri. Tanggung jawab dan kemandirian anak usia dini harus dilihat berdasarkan tingkat usia anak itu.

Uraian di atas menekankan pentingnya pembinaan aspek perkembangan kemandirian pada anak usia dini. Oleh karena itu, penelitian ini memberikan gambaran secara kuantitatif dengan menyajikan tingkat persentase variabel indefenden $(\mathrm{X})$ berpengaruh pada variabel defenden $(\mathrm{Y})$. Selanjutnya dikonversi menjadi nilai kualitatif untuk mengetahui kualitas pengaruh pelaksanaan program parenting terhadap perkembangan kemandirian peserta didik pada PAUD Paramata Bunda Kota Palopo.

Hasil analisis variabel X (indefenden) mendeskripsikan bahwa orang tua peserta didik mengikuti kegiatan program parenting, dapat dilihat pada tabel berikut.

\section{Tabel 3}

Pelaksanaan Program Parenting

PAUD Paramata Bunda Kota Palopo

(Variabel X)

\begin{tabular}{clcc}
\hline No. & Jenis Program Parenting & Persentase & Kategori \\
\hline 1 & Opening school & 95,31 & $\mathrm{~A}$ \\
2 & Silaturrahim & 92,18 & $\mathrm{~A}$ \\
3 & Memperingati hari besar & 93.75 & $\mathrm{~A}$ \\
& keagamaan/nasional & & \\
4 & Tadabbur alam & 92,18 & $\mathrm{~A}$ \\
5 & Life Skill & 98,44 & $\mathrm{~A}$ \\
6 & Workshop parenting & 92,97 & $\mathrm{~A}$ \\
7 & Senam massal dan jalan santai & 89,06 & $\mathrm{~A}$ \\
\hline & $\quad$ Jumlah & 653,89 & - \\
\hline & Rata-rata & 93,42 & $\mathrm{~A}$ \\
\hline
\end{tabular}

Data pada tabel di atas mendeskripsikan bahwa program parenting pada PAUD Paramata Bunda Kota Palopo dapat dilaksanakan oleh orang tua peserta didik dengan persentase keikutsertaannya rata-rata 93,42\%, secara kontinum berada pada interval 85 sampai dengan 100. Angka persentase ini jika dikonversi ke nilai kualitas, maka menjadi kategori A atau sangat baik. Dalam perkataan lain bahwa program parenting pada PAUD Paramata Bunda Kota Palopo (variabel X) mempunyai pengaruh yang sangat baik.

Selanjutnya, diuraikan paparan hasil analisis variabel Y (defenden). Berdasarkan hasil analisis variabel Y (defenden) mendeskripsikan perkembangan kemandirian peserta didik dapat dilihat pada tabel berikut. 
Tabel 4

Perkembangan Kemandirian Peserta Didik pada

PAUD Paramata Bunda Kota Palopo

(Variabel Y)

\begin{tabular}{|c|c|c|c|}
\hline No. & Indikator Perkembangan & Persentase & Kategori \\
\hline 1 & $\begin{array}{l}\text { Berpisah dengan orangtuanya } \\
\text { tanpa menangis }\end{array}$ & 87,50 & A \\
\hline 2 & Memilih kegiatan sendiri & 83,33 & B \\
\hline 3 & $\begin{array}{l}\text { Bermain sesuai dengan jenis } \\
\text { permainan yang dipilihnya }\end{array}$ & 95,83 & A \\
\hline 4 & $\begin{array}{l}\text { Mengurus dirinya dengan } \\
\text { bantuan }\end{array}$ & 79,16 & B \\
\hline 5 & Pergi dan pulang sekolah sendiri & 33,33 & $\mathrm{D}$ \\
\hline 6 & $\begin{array}{l}\text { Mandi sendiri, gosok gigi, BAK } \\
\text { dan BAB }\end{array}$ & 83,33 & B \\
\hline 7 & Mengerjakan tugas sendiri & 85,41 & A \\
\hline & Jumlah & 547,89 & - \\
\hline & Rata-rata & 78,27 & B \\
\hline
\end{tabular}

Data pada tabel di atas mendeskripsikan bahwa perkembangan kemandirian peserta didik pada PAUD Paramata Bunda Kota Palopo rata-rata $78,27 \%$ secara kontinum berada pada interval 75 sampai dengan 84 . Angka persentase ini jika dikonversi ke nilai kualitas, maka menjadi kategori B atau baik. Dalam perkataan lain bahwa perkembangan kemandirian peserta didik pada PAUD Paramata Bunda Kota Palopo (variabel Y) kategori baik.

Berdasarkan hasil analisis kedua variabel di atas, maka selanjutnya dipresentasikan tentang deskripsi pengaruh program parenting (variabel $\mathrm{X}$ ) terhadap perkembangan kemandirian peserta didik anak usia dini (variabel Y) pada PAUD Paramata Bunda Kota Palopo. Diketahui bahwa persentase pelaksanaan program parenting adalah 93,42\% atau kategori sangat tinggi. Hal ini berarti bahwa keikutsertaan orang tua peserta didik dalam penyelenggaraan kegiatan pendidikan pada PAUD Paramata Bunda sangat tinggi. Orang tua peserta didik menunjukkan perhatian yang optimal dalam mendukung keberlangsungan pendidikan anaknya pada PAUD Paramata Bunda.

Sedangkan persentase perkembangan kemandirian peserta didik adalah 78,27\%, atau kategori tinggi. Hal ini berarti bahwa perkembangan kemandirian peserta didik pada PAUD Paramata Bunda Kota Palopo belum optimal. Masih ada aspek perkembangan kemandirian yang perlu mendapat perhatian baik dari orang tua peserta didik maupun dari guru mereka. Dari hasil analisis, diketahui masih ada beberapa indikator aspek kemandirian yang 
perlu mendapat perhatian, di antaranya memilih kegiatan sendiri, mandi sendiri, gosok gigi, BAK dan BAB, serta pergi dan pulang sekolah sendiri.

Dengan demikian, dapat dikatakan bahwa program parenting berpengaruh positif dan signifikan walaupun belum optimal terhadap perkembangan kemandirian anak usia dini pada PAUD Paramata Bunda Kota Palopo.

\section{PENUTUP}

Berdasarkan uraian sebelumnya maka hasil penelitian ini disimpulkan sebagai berikut.

1. Program parenting pada PAUD Paramata Bunda Kota Palopo meliputi: kegiatan opening school (melibatkan seluruh orang tua), silaturrahim dengan orang tua setiap bulan membahas perkembangan anak, memperingati hari besar keagamaan dan hari besar nasional, tadabbur alam (untuk memperkenalkan pada anak macam-macam tumbuhan), life skill (meliputi membuat asesoris dan bros terbuat dari barang bekas perca kain), serta memasang payet, workshop parenting, dan senam massal serta jalan santai setiap akhir semester dapat dilaksanakan dengan sangat baik, indikatornya adalah akumulasi pelaksanaan ketujuh program tersebut mencapai 92,30\%.

2. Sikap kemandirian anak pada PAUD Paramata Bunda Kota Palopo mengalami perkembangan yang baik, indikatornya adalah akumulasi perkembangan kemandirian peserta didik mencapai 78,27\%.

3. Pelaksanaan program parenting pada PAUD Paramata Bunda kategori sangat baik, indikatornya yaitu memperoleh nilai 93,42\%. Hal ini berarti bahwa keikutsertaan orang tua peserta didik dalam penyelenggaraan kegiatan pendidikan pada PAUD Paramata Bunda sangat tinggi. Orang tua peserta didik menunjukkan perhatian yang optimal dalam mendukung keberlangsungan pendidikan anaknya. Sedangkan persentase perkembangan kemandirian anak usia dini kategori baik, indikatornya yaitu memperoleh nilai 78,27\%. Dengan demikian, program parenting berpengaruh positif terhadap perkembangan kemandirian anak usia dini pada PAUD Paramata Bunda Kota Palopo.

\section{DAFTAR PUSTAKA}

Arikunto, Suharsimi. Prosedur Penelitian Suatu Pendekatan Praktik. Cet. XIII; Jakarta: Rineka Cipta, 2006.

Baqi, Muhammad Fuad Abdul. Al-Lu'lu wal Marjan Fima Ittafaqa Alaihi asySyaikhani Al-Bukhary wa Muslim. Terj. Arief Rahman Hakim dengan judul: Kumpulan Hadist Shahih Bukhary Muslim. Solo: Insan Kamil Solo, 2012. 
174 | Syamsu $S$.

Danim, Sudarwan. Perkembangan Peserta Didik. Cet. I; Bandung: Alfabeta, 2010.

Daradjat, Zakiyah. Ilmu Jiwa Agama. Cet. V; Jakarta: Bulan Bintang, 2005.

Departemnen Agama RI. Al-Qur'an dan Terjemahnya. Semarang: Asy-Syifa', 2000.

Republik Indonesia. Undang-Undang Nomor 20 Tahun 2003 tentang Sistem Pendidikan Nasional. Cet. IV; Jakarta: Sinar Grafika, 2011.

Sugiyono. Metode Penelitian Kuantitatif, Kualitatif, dan R\&D. Cet. XIII; Bandung, Alfabeta, 2011.

Sukmadinata, Nana Syaodih. Metode Penelitian Pendidikan. Cet. III; Bandung: Remaja Rosdakarya, 2007.

Sunarto. Perkembangan Peserta Didik. Cet. II; Jakarta: Rineka Cipta, 2002.

Tiro, Muh. Arif. Dasar-dasar Statistik. Makassar: UNM, 2000.

Usman, Husaini, dan Purnomo Setiady Akbar. Metodologi Penelitian Sosial. Cet. III; Jakarta: Bumi Aksara, 2009.

Yusuf L.N., Syamsu, dan Nani M. Sugandhi. Perkembangan Peserta Didik. Cet. III; Jakarta: RajaGrafindo Persada, 2012. 